\title{
Reduced egfr, elevated urine protein and low level of personal protective equipment compliance among artisanal small scale gold miners at Bibiani-Ghana: a cross- sectional study
}

\author{
Justice Afrifa* (1D, Samuel Essien-Baidoo, Richard K.D. Ephraim, Daniel Nkrumah and Daniel Osei Dankyira
}

\begin{abstract}
Background: Mercury is a toxic metal with its effects on human health ranging from acute to chronic in a very short time of exposure. Artisanal and small-scale gold mining (ASGM) is the main source of direct human exposure to mercury.

Aim: To access the effect of mercury exposure on the renal function and level of personal protective equipment (PPE) compliance among small-scale gold miners in Bibiani District of the Western Region of Ghana

Method: 110 consenting male gold miners were purposively recruited for this study. A structured questionnaire was used to collect socio-demographic information from the participants. Work place assessment and interviews were conducted. Urine samples were analysed for protein; blood was analysed for mercury and creatinine. Estimated glomerular filtration rate (eGFR) was calculated using the chronic kidney disease-epidemiology collaboration (CKD-EPI) equation.

Results: Of the 110 participants, 61(55.5\%) exceeded the occupational exposure threshold (blood mercury <5 $\mu \mathrm{g} / \mathrm{L})$. Urine protein $(41.72 \pm 68.34, \mathrm{P}<0.0001)$, serum creatinine $(2.24 \pm 1.19, \mathrm{P}<0.0001)$ and blood mercury $(18.37 \pm 10.47, \mathrm{P}<0.0001)$ were significantly elevated among the exposed group compared to the non-exposed group. However, the exposed group had a significantly reduced eGFR ( $P<0.0001)$. There was a significant correlation $(r=0.7338, p<0.0001)$ between blood mercury concentration and urine protein concentration. An increase in blood mercury correlated negatively $(r=-0.8233, P<0$. 0001) with eGFR among the exposed group. High urine protein $(P<0.0001)$ and high serum creatinine $(P<0.0001)$ were significantly associated with increased mercury exposure. Increased mercury exposure was significantly associated with burning of amalgam ( $P=0.0196)$, sucking of excess mercury $(P=0.0336)$, longer work duration $(P=0.0314)$ and low educational background ( $P=0.0473)$.
\end{abstract}

Conclusion: Small scale miners at the Bibiani work site are exposed to excess mercury. Proteinuria and reduced eGFR is common in mine workers exposed to excess mercury. We found poor PPE compliance among the study population.

Keywords: Small scale mining, Mercury exposure, Renal function

\footnotetext{
* Correspondence: jafrifa@ucc.edu.gh

Department of Medical Laboratory Technology University of Cape Coast,

Cape Coast, Ghana
} 


\section{Background}

The Artisanal Small Scale Mining (ASGM) sector is very active in Ghana, and its importance is steadily growing [1]. Several health concerns exists in small-scale gold mining communities such as exposure to mercury, dust and noise, unsanitary working conditions and lack of personal protective equipment for gold mining [2].

ASGMs use mercury amalgamation to produce gold, a process which puts them at risk of exposure to mercury [2]. Exposure to mercury can occur through routes such as dermal, oral, and inhalation. Inhalation of significant concentrations of mercury vapour during processing and extraction of gold is the main route of exposure [3]. If ingested, quicksilver which is liquid at room temperature has very low toxicity because it is not absorbed by the gastrointestinal tract and is eliminated completely in the stool. Mercury is known to be toxic even at low concentrations [4]. High levels of mercury exposure deplete the amount of cellular selenium available for the biosynthesis of thioredoxin reductase and other selenoenzymes that prevent and reverse oxidative stress [5]. This can increase oxidative stress on visceral organs such as the liver and the kidney leading to potential organ damage. The kidneys are one of the main target organs for elemental mercury, with high accumulation especially in the areas of the proximal tubule [6]. Experimental studies carried out in animals revealed immunologically mediated glomerulonephritis after exposure to mercury [6] .

An estimated 1 million Ghanaians are directly involved in small-scale mining [7]. In Ghana, the main environmental problems associated with ASGM activities are mercury pollution from gold processing, ecosystems destruction and environmental degradation [8]. The small-scale gold miners in the mining site at Bibiani are known to handle the mercury without the use of appropriate PPEs like nasal and skin protectors. Occupationally, those involved in small-scale gold mining (both directly and indirectly) may inhale high levels of elemental mercury which is readily absorbed into the blood stream [2]. Prolonged exposure to mercury vapour at concentrations greater then $100 \mathrm{mg} / \mathrm{m}^{3}$ usually results in insidious onset of symptoms which when not attended to may lead to a chronic effect [9]. In Ghana, studies conducted among artisanal and small scale gold miners focused on various factors ranging from environmental and neurotoxic health risk [10], ASGM and living conditions [11] through to regulation of ASGM [12]. However, none considered the effect of mercury exposure on renal function especially in a population that works without recourse to safety procedures. Thus, we sought to assess the effect of mercury exposure on the renal function of small-scale miners in the Bibiani District of the Western region of Ghana.

\section{Methodology \\ Study area}

This cross-sectional study was conducted in Bibiani, an old gold mining town, in the Bibiani -Anhwiaso - Berkwai District in the North-Western part of the Western Region of Ghana (Fig. 1). Bibiani, the district capital, is $88 \mathrm{~km}$ from Kumasi in the Ashanti Region and $356 \mathrm{~km}$ from the western regional capital, Takoradi. The town has a large gold mining company called Mensin Gold Mining Company.

There are two small-scale gold mining sites in Bibiani namely Donkoto and Zongo sites respectively. The actual gold extraction is done at the Donkoto site. Zongo site is situated near a lake called Amponsem where the crushing, milling, washing, panning and amalgamation processes are done. The Zongo site is about 390 yards $(380 \mathrm{~m})$ in length and the width not between 150 yards $(140 \mathrm{~m})$ and 300 yards $(290 \mathrm{~m})$.

\section{Study population and sampling}

We purposively sampled 110 male small scale gold miners staying in Bibiani. All the participants were actively involved in small-scale gold mining at the time of the study.

\section{Inclusion criteria}

The small-scale miners were recruited based on the following criteria: at least 1-year exposure to mercury; no history of occupational exposure to lead, cadmium and other nephrotoxic substances; no evidence of haematuria, pyuria, glycosuria or urinary tract infection in the first two years of occupational exposure to mercury; no history of renal diseases, diabetes mellitus and no evidence of consumption of analgesics and antibiotics usage two weeks prior to the examination.

\section{Exclusion criteria}

Small-scale miners who failed to give an informed consent and persons not engaging in small scale gold mining in Bibiani were excluded from the study. Smallscale miners that had a history of occupational exposure to lead, cadmium and other nephrotoxic substances, disease conditions and infections that can interfere with urinary protein estimation and consumption of analgesics and antibiotics two weeks prior to the examination were also excluded from the study. Weight lifters at the mine site were also excluded from the study.

\section{Data collection}

A pre-tested structured-questionnaire was administered to the 110 consenting participants to collect their sociodemographic characteristics, occupational exposure and 


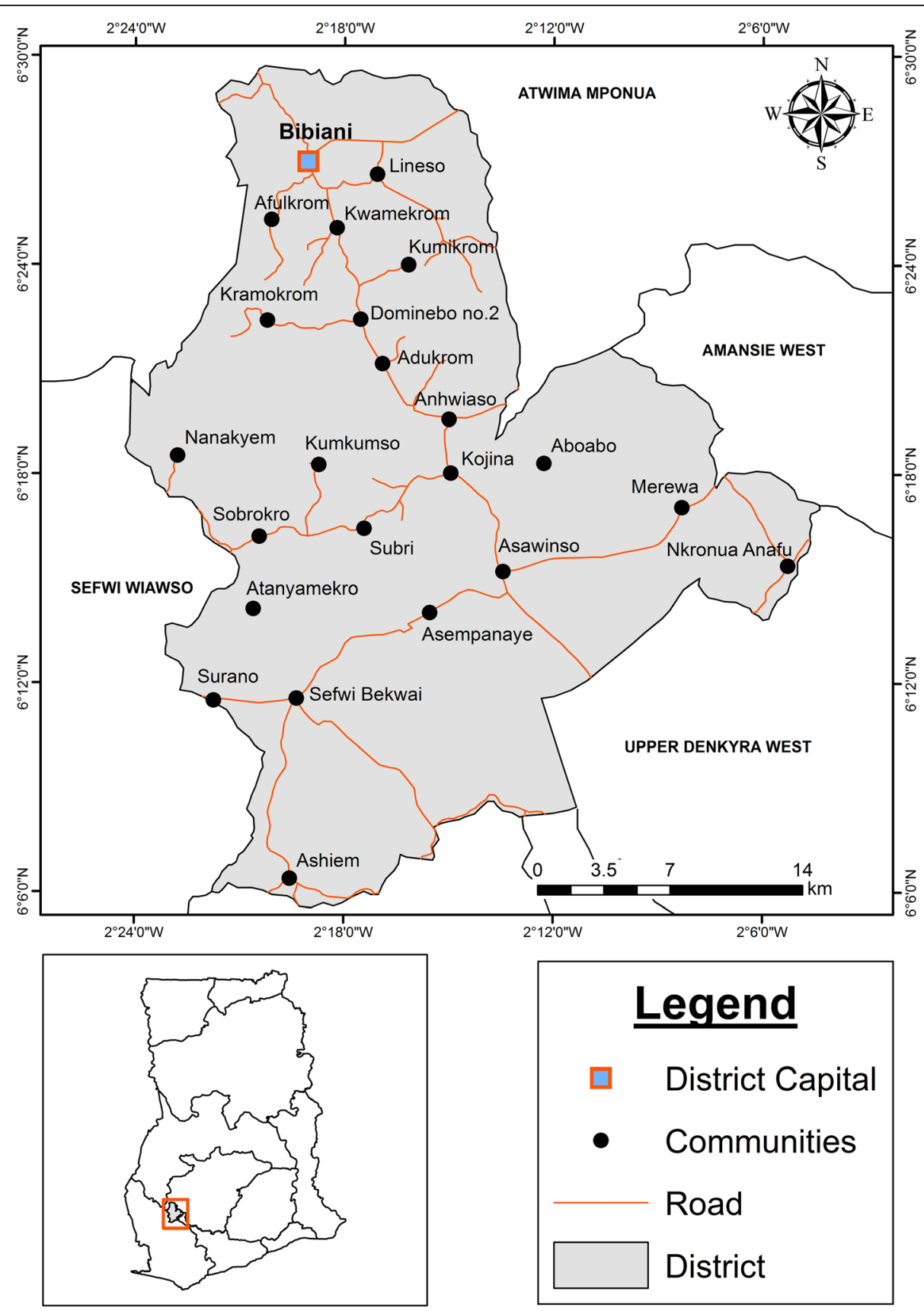

Fig. 1 District Map of Bibiani -Anhwiaso - Berkwai, with the sampling site indicated in red

safety, and presence of signs and symptoms suggestive of mercury exposure.

\section{Urine sample collection}

Twenty (20)-50 $\mathrm{ml}$ of random spot urine samples was collected from each participant at the work site into clean plastic bottles. All urine containers were properly labelled using the identifying numbers of participants. Safety precautions were employed in the collection of the urine samples to avoid contamination.

\section{Blood sample collection and transportation}

Five (5) mls of blood sample was collected using sterilized syringes and needles. Three (3) mls of the blood sample was put into tripotassium ethylenediaminetetracetic acid ( $K_{3}$ EDTA) tubes and the rest into serum separator tubes. Samples were kept inside a cold plastic box containing ice packs in the field. All the samples were transported to the Laboratory at Bibiani District Hospital. Blood samples in the serum separator tubes were centrifuged at $1000 \mathrm{rpm}$ for $10 \mathrm{~min}$ to obtain the serum 
which was adequately labelled and stored at $-20{ }^{\circ} \mathrm{C}$. Samples were then kept on ice packs and were transported to the Research Laboratory of the Medical Laboratory Technology Department, University of Cape Coast.

\section{Blood sample preparation and transportation Wet digestion}

The test solutions for blood mercury analysis were prepared at the Research Laboratory in the School of Agricultural of the University of Cape Coast. Two (2) grams of blood sample was transferred to the bottom of a thickwalled volumetric digestion flask, $6 \mathrm{ml}$ of conc. $\mathrm{HNO}_{3}$, and $1 \mathrm{ml}$ of $30 \% \mathrm{H}_{2} \mathrm{O}_{2}$ were added in turn and the mixture was heated at a temperature of $45{ }^{\circ} \mathrm{C}$ inside a block digester machine (model: EFA-5UDRVW-8) for $3 \mathrm{~h}$. The mixture was allowed to cool and distilled water was added to make a fixed volume of $30 \mathrm{ml}$, it was well mixed, and the resulting solution was used as the sample test solution.

Samples were kept inside mercury free plastic containers and transported to Ghana Atomic Energy Commission (GAEC) in Accra for mercury analysis. The Cold Vapour Atomic Absorption Spectrophotometer (CVAAS), machine (varian model AA240FS), with a detection limit of $0.01 \mu \mathrm{g} / \mathrm{L}$ was used for the analysis. The certified reference materials (CRM) used was obtained from TraceCERT $^{\circ}$, SIGMA-ALDRICH ${ }^{\oplus}$, USA. Individuals with mercury levels $\geq 5.0 \mu \mathrm{g} / \mathrm{L}$ were considered as occasionally exposed and those with mercury levels $<5.0 \mu \mathrm{g} /$ $\mathrm{L}$ were considered as non-exposed [13-15]

\section{Urine protein determination}

Urine protein was measured immediately after collection. Proteinuria was assessed semi-quantitatively using dipstick. This was converted into a continuous scale by categorizing as negative (less than $10 \mathrm{mg} / \mathrm{dL}$ ), trace $(10$ to $20 \mathrm{mg} / \mathrm{dL}),+1(30 \mathrm{mg} / \mathrm{dL}),+2(100 \mathrm{mg} / \mathrm{dL})$, +3 $(300 \mathrm{mg} / \mathrm{dL})$ or $+4(1000 \mathrm{mg} / \mathrm{dL})[16,17]$.

Serum creatinine measurement/eGFR estimation

Serum creatinine was estimated with an automated chemistry analyzer (model: UV-mini-1240) with a detection limit of $0.1 \mathrm{umol} / \mathrm{L}$ was used at the University of Cape Coast Hospital Laboratory for the measurement of serum creatinine levels. The principle for estimation was based on the Jaffe's technique [18]. eGFR was estimated using the CKD-EPI eq. [19]

\section{Data analysis}

Data was sorted, entered and analyzed using Graph pad prism version 6.01. Exploratory analysis was carried out to obtain descriptive statistics such as frequencies, percentages, Mean \pm Standard Deviation(SD), figures and tables. Kruskal Wallis test was used to compare the difference between the mercury concentrations, urine protein and estimated glomerular filtration rates among study participants based on their work durations. Spearman rho moment correlation analysis was done to determine correlation between mercury concentration and urine protein as well as the estimated glomerular filtration rate of the occupationally exposed participants. Mann-Whitney test was used to compare the renal function indicators of the occupationally exposed and non-exposed participants respectively. Fisher's Exact test was used to estimate the Odds Ratio for the multivariate logistic regression of various occupational activities and educational status as well as renal biomarkers associated with mercury exposure. Multivariate logistic regression was used to estimate the age

Table 1 Socio-demographics and renal characteristics of the study participants

\begin{tabular}{|c|c|c|c|}
\hline Variable & $\begin{array}{l}\text { Exposed (\%) } \\
N=61\end{array}$ & $\begin{array}{l}\text { Non-exposed (\%) } \\
N=49\end{array}$ & $p$-value \\
\hline Age (Years) & $35.77 \pm 11.61$ & $33.96 \pm 9.678$ & 0.3838 \\
\hline$\leq 19$ & $2(3.3)$ & $4(8.2)$ & 0.2863 \\
\hline $20-39$ & $40(65.6)$ & $36(73.5)$ & \\
\hline $40-59$ & $17(27.8)$ & $7(14.2)$ & \\
\hline$\geq 60$ & $2(3.3)$ & $2(4.1)$ & \\
\hline Marital status & & & 0.0202 \\
\hline Married & $41(67.2)$ & 19 (38.8) & \\
\hline Divorced & $2(3.3)$ & $1(2.0)$ & \\
\hline Single & $17(27.8)$ & $27(55.1)$ & \\
\hline Widowed & $1(1.6)$ & $2(4.1)$ & \\
\hline Highest level of educatior & & & 0.1684 \\
\hline Uneducated & $14(23.0)$ & $6(12.2)$ & \\
\hline Primary & $31(50.8)$ & $23(46.9)$ & \\
\hline Secondary & $16(26.2)$ & $20(40.8)$ & \\
\hline Ethnicity & & & 0.1382 \\
\hline Akan & $45(73.8)$ & $32(65.3)$ & \\
\hline Dagomba & $10(16.3)$ & $5(10.2)$ & \\
\hline Frafra & $4(6.6)$ & $5(10.2)$ & \\
\hline Grussi & $2(3.3)$ & $7(14.3)$ & \\
\hline Work duration (Years) & $14.72 \pm 10.67$ & $10.77 \pm 7.305$ & 0.0316 \\
\hline$<5$ & $9(14.75)$ & $11(22.44)$ & 0.3287 \\
\hline$\geq 5$ & $52(85.25)$ & $38(77.55)$ & \\
\hline Work duration(hours) & $9.39 \pm 2.73$ & $9.425 \pm 2.27$ & 0.942 \\
\hline Urine Protein(mg/dL) & $41.72 \pm 68.34$ & $0.6122 \pm 3.00$ & $<0.0001$ \\
\hline Negative & 20(32.79) & $45(91.84)$ & $<0.0001$ \\
\hline Positive & $41(67.21)$ & $4(8.16)$ & \\
\hline Creatinine $(\mu \mathrm{mol} / \mathrm{L})$ & $2.24 \pm 1.19$ & $0.974 \pm 0.184$ & $<0.0001$ \\
\hline $\mathrm{eGFR}\left(\mathrm{mL} / \mathrm{min} / 1.73 \mathrm{~m}^{2}\right)$ & $57.02 \pm 29.57$ & $120.4 \pm 20.57$ & $<0.0001$ \\
\hline Blood mercury( $\mu \mathrm{g} / \mathrm{L})$ & $18.37 \pm 10.47$ & $2.90 \pm 1.387$ & $<0.0001$ \\
\hline
\end{tabular}

eGFR = Estimated glomerular filtration rate 
adjusted odds ratio for the renal biomarkers. Significance level was determined at $p<0.05$.

\section{Results}

Table 1 compares various socio-demographic parameters and biochemical characteristics of study participants stratified by exposure and non-exposure to mercury. Compared to the non-exposed group, exposed participants were married $(P=0.0202)$, had worked for a longer

Table 2 Frequency of reported signs and symptoms of mercury exposure among study participants

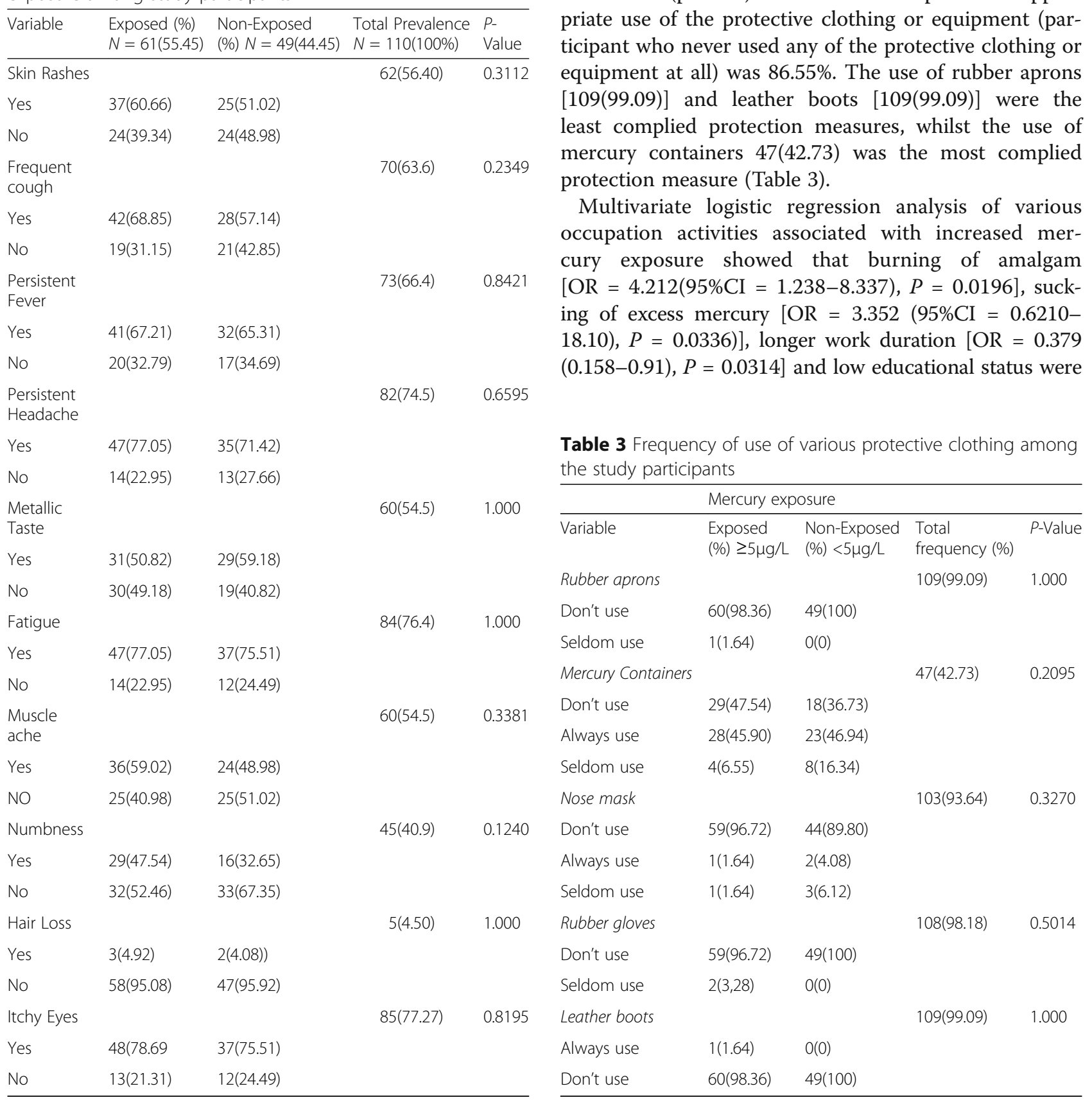

duration $(P=0.0316)$ and had higher levels of urine protein $(P<0.0001)$ and creatinine $(P<0.0001)$. However, eGFR, was significantly reduced $(P<0.0001)$ among the small-scale miners who were exposed.

The most common symptoms of mercury exposure among the study participants were itchy eyes [85(77.270)], fatigue [84(76.4)] and persistent headache [82(74.5)]. Hair loss was least reported among the various signs and symptoms assessed. However, there was no significance difference $(P>0.005)$ in the reported signs and symptoms when the exposed were compared to the non-exposed (Table 2).

The total (percent) absolute non-compliance of appropriate use of the protective clothing or equipment (participant who never used any of the protective clothing or equipment at all) was $86.55 \%$. The use of rubber aprons [109(99.09)] and leather boots [109(99.09)] were the least complied protection measures, whilst the use of mercury containers 47(42.73) was the most complied rotection measure (Table 3).

Multivariate logistic regression analysis 18.10), $P=0.0336)]$, longer work duration $[\mathrm{OR}=0.379$

Table 3 Frequency of use of various protective clothing among the study participants 
Table 4 Multivariate logistic regression analysis of various occupational activities and educational status associated with mercury exposure

\begin{tabular}{|c|c|c|c|c|}
\hline Variable & Exposed $N=61$ & Non-exposed $N=49$ & Crude OR(95\%Cl) & $P$ value \\
\hline \multicolumn{4}{|l|}{ Gold Amalgamation } & 1.0000 \\
\hline Yes & $59(96.7)$ & $48(97.9)$ & $0.6146(0.054-6.989)$ & \\
\hline NO & $2(3.3)$ & $1(2.1)$ & * & \\
\hline \multicolumn{4}{|l|}{ Burning of Amalgam } & 0.0196 \\
\hline Yes & $53(86.9)$ & $33(67.3)$ & $3.212(1.238-8.337)$ & \\
\hline No & $8(13.1)$ & $16(32.7)$ & * & \\
\hline \multicolumn{4}{|l|}{ Smelting of Gold } & 1.000 \\
\hline Yes & $58(86.9)$ & $47(95.9)$ & $0.8227(0.1319-5.13)$ & \\
\hline NO & $3(13.1)$ & $2(4.1)$ & * & \\
\hline \multicolumn{4}{|c|}{ Transportation of mercury } & 0.2384 \\
\hline Yes & $59(96.7)$ & $44(89.8)$ & $3.352(0.6210-18.10)$ & \\
\hline NO & $2(3.3)$ & $5(10.2)$ & * & \\
\hline \multicolumn{4}{|c|}{ Standing in pool of water stream } & 0.1064 \\
\hline Yes & $58(86.9)$ & $42(85.7)$ & $3.222(0.7867-13.20)$ & \\
\hline No & $3(13.1)$ & $7(14.3)$ & $*$ & \\
\hline \multicolumn{4}{|c|}{ Sucking of excess mercury } & 0.0336 \\
\hline Yes & $53(86.9)$ & $34(69.4)$ & $2.923(1.119-7.636)$ & \\
\hline No & $8(3.3)$ & 15 (30.6) & $*$ & \\
\hline \multicolumn{4}{|l|}{ Work Duration(years) } & 0.0314 \\
\hline$<5$ & $11(18.0)$ & $18(36.7)$ & * & \\
\hline$\geq 5$ & $50(82.0)$ & $31(63.3)$ & $2.639(1.101-6.32)$ & \\
\hline \multicolumn{4}{|c|}{ Fish consumption from lake } & 1.0000 \\
\hline Yes & $33(54.1)$ & $27(55.1)$ & $0.960(0.451-2.04)$ & \\
\hline NO & $28(45.9)$ & $22(44.9)$ & * & \\
\hline \multicolumn{4}{|l|}{ Previous work } & 0.8382 \\
\hline Yes & $19(31.1)$ & $17(34.7)$ & $0.8515(0.38-1.89)$ & \\
\hline No & $42(68.9)$ & $32(65.3)$ & * & \\
\hline \multicolumn{5}{|c|}{ Place of mercury storage } \\
\hline Don't store Mercury & $3(4.9)$ & $2(4.1)$ & $*$ & \\
\hline Home & $43(70.5)$ & $31(63.3)$ & $0.925(0.146-5.87)$ & 1.000 \\
\hline Mine Site & $15(24.6)$ & $16(32.6)$ & $0.625(0.091-4.27)$ & 1.000 \\
\hline \multicolumn{4}{|c|}{ Knowledge of mercury intoxication } & 0.8447 \\
\hline Yes & $24(39.3)$ & $18(36.7)$ & $1.117(0.514-2.42)$ & \\
\hline NO & $37(60.7)$ & $31(63.3)$ & * & \\
\hline \multicolumn{5}{|c|}{ Highest level of education } \\
\hline Uneducated & $14(23.0)$ & $5(10.2)$ & $3.675(1.09-12.34)$ & 0.0473 \\
\hline Primary & $31(50.8)$ & $23(47.0)$ & $1.77(0.7598-4.12)$ & 0.206 \\
\hline Secondary & $16(26.2)$ & $21(42.8)$ & * & \\
\hline
\end{tabular}

significantly associated with increased mercury exposure. (Table 4)

Age-AOR = Age Adjusted Odds Ratio

High urine protein $[\mathrm{OR}=50.29(95 \% \mathrm{CI}=10.97-$ 230.53, $P<0.0001]$, and elevated serum creatinine
$[\mathrm{OR}=101.6(95 \% \mathrm{CI}=25.45-405.7), P<0.0001)$ are associated with high mercury exposure. Reduced eGFR $[\mathrm{OR}=263.2(95 \% \mathrm{CI}=48.79-1420), P<0.0001]$ was associated with increased mercury exposure among small scale miners when adjusted for age (Table 5). 
Table 5 Multivariate logistic regression analysis of renal biomarkers associated with mercury exposure

\begin{tabular}{|c|c|c|c|c|}
\hline \multirow[b]{2}{*}{ Variable } & \multicolumn{4}{|c|}{ Mercury Exposure } \\
\hline & Exposed (\%) & Non -exposed (\%) & Age-AOR (95\% Cl) & $P$-value \\
\hline \multicolumn{5}{|c|}{ Urine protein (mg/dl) } \\
\hline Normal $(<10)$ & $20(32.79)$ & $47(95.9)$ & * & \\
\hline High ( $\geq 10)$ & $41(67.21)$ & $2(4.1)$ & 50.29 (10.97-230.53) & $<0.0001$ \\
\hline \multicolumn{5}{|c|}{ eGFR (mL/min/1.73m²) } \\
\hline Normal (>90) & $5(8.2)$ & 47 (95.91) & * & \\
\hline Low $(\leq 90)$ & $56(91.8)$ & $2(4.1)$ & 263.2(48.79-1420) & $<0.0001$ \\
\hline \multicolumn{5}{|l|}{ Creatinine $(\mu \mathrm{mol} / \mathrm{L})$} \\
\hline Normal (53-106) & $8(13.1)$ & $46(75.4)$ & * & \\
\hline High (>106) & $53(86.9)$ & $3(24.6$ & $101.06(25.23-404.85)$ & $<0.0001$ \\
\hline
\end{tabular}

\section{Discussion}

We sought to assess the effect of mercury exposure on the renal biomarkers and level of PPE compliance of ASGMs working at the Bibiani mine site. Our findings showed that increased proteinuria and reduced eGFR were common among the miners exposed to higher levels of mercury; increased renal abnormalities were related to longer working duration and low PPE compliance.

Majority of the participants were exposed to mercury above the exposure threshold in consonance with earlier studies conducted in South Africa, Brazil and Ghana which reported $50 \%, 48.3 \%$ and 46.65 of the participants having elevated urine mercury concentration respectively $[14,20,21]$. Urine mercury levels have been shown to directly correlate strongly with blood mercury [22] and thus urine concentration usually reflects blood mercury concentration. De Kom et al. also reported high serum mercury levels in a case-control study among Maroon workers in small-scale gold mines in Suriname [23].

The kidneys are the main target organs for elemental mercury besides the central nervous system [24]. The reduced glomerular filtration rate among the study

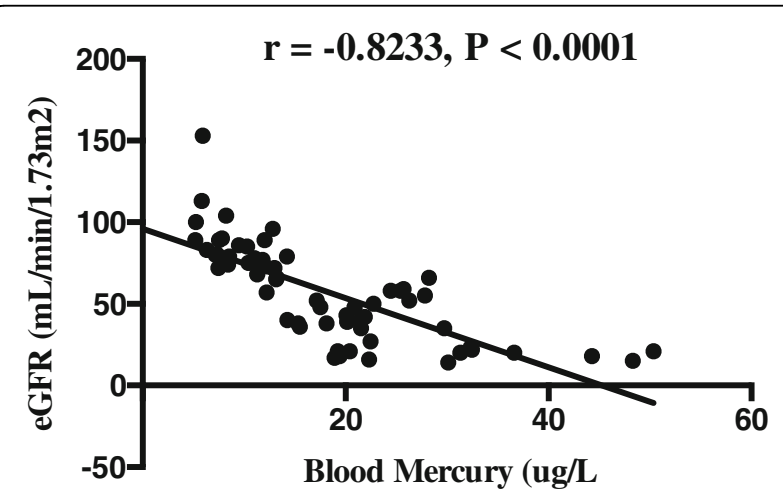

Fig. 2 Scatter plot and Spearman rho moment correlation between blood mercury and eGFR of exposed participantsBlood mercury levels correlated positively $(r=0.7338, p<0.0001)$ with proteinuria but negatively ( $r=-0.8233, p<0.0001)$ with eGFR (Figs. 2 and 3 ) participants, as well as the elevated serum creatinine is an indication of renal function impairment. Augusti et al., (2007) [25] on the assessment of the effects of astaxanthin on kidney function impairment and oxidative stress induced by mercury chloride in rats also reported a reduced glomerular filtration as a consequence of elevated serum creatinine after mercury injection. In line with the findings of Kobal and co [26] we reported a negative correlation between blood mercury levels and eGFR (Fig. 2) among miners intermittently exposed to mercury.

Proteinuria is a clinical manifestation of mercury intoxication due to elemental inorganic and ethyl mercury [27]. In agreement with earlier studies in Sekotong, West Lambork-Indonesia [16, 28], and in Irija mines in Nigeria [16] we noted a significant increase in proteinuria among mine workers exposed to higher levels of mercury (Fig. 3). Persistent proteinuria indicates kidney disease [29] and within the kidney, the pars recta of the proximal tubule has been known to be the most vulnerable segment of the nephron that is susceptible to the toxic effects of mercury [30].

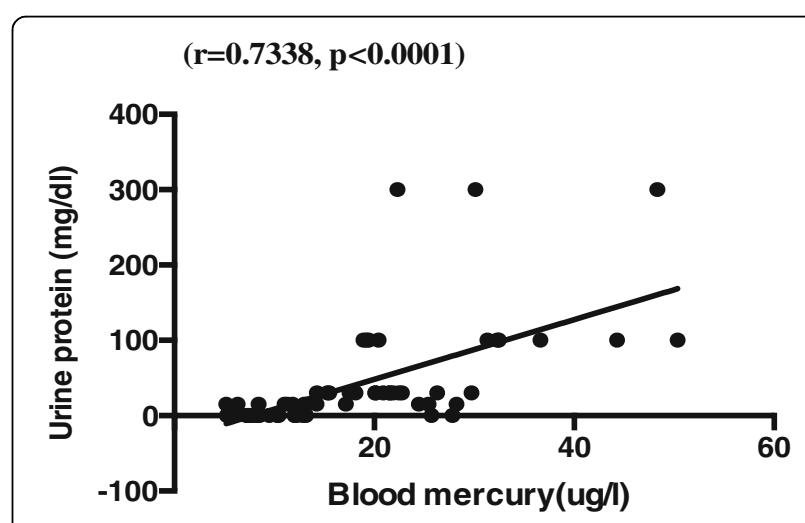

Fig. 3 Scatter plot and Spearman rho moment correlation between blood mercury and urine protein of exposed participants 
The extent of renal dysfunction has been severally related to extent of mercury exposure, route of exposure, the state of the mercury and the duration of exposure [31]. Franko and Dodic-Fikfak [28] reported the duration for the commencement of clinical manifestation among small scale gold miners to be 15 years in a case controlstudy in Idrija mercury mines. Similarly, we report a mean duration of 14.72 years as the duration for the presentation of renal abnormalities with participants who have worked for more than 5 years at the Bibiani mines being likely to present with elevated blood mercury above the occupational threshold.

Various signs and symptoms ranging from skin rashes through persistent headaches to hair loss have been reported as associated with the use of mercury in smallscale mining. These may vary from location to location as well as extent of exposure [2]. Whiles we report "itchy eyes" and fatigue as the most common sign and symptom suggestive of mercury exposure, Mensah in 2012, reported complaints of skin rashes, red eyes and metallic taste to be associated with mercury exposure among small scale miners in Prestea, Ghana [2] . Other studies have reported red eyes and conjunctivitis among individuals exposed to high concentration of elemental mercury vapours [32]. This could be attributed to continuous higher occupational exposure to elemental mercury vapour.

According to WHO, the main route of mercury exposure in ASGM is inhalation of vaporized elemental mercury released during amalgam smelting [33]. However, we observed a very low compliance with PPE use among our participants (Table3). In line with a study by Hilson et al., [34] in the Talensi-Nabdam District of Ghana, we recorded limited use of PPE among small- scale miners even though some were aware of the of the health risks associated with mercury thus corroborating the findings of Rojas et al., [35]. The high non-compliance with the use of PPEs may be attributed to the low level of education and apathy, since majority of the participants were either uneducated or had only basic education. Also, most of the participants did not have any form of occupational safety training in mercury processing and handling. The clinical interpretations of our findings may be limited due to the lack of pure controls who are not miners and our inability to measure urine mercury which is a better biomarker for chronic mercury exposure. A study considering the specific dose of mercury exposure will provide further information on the duration and extent of renal derangement.

\section{Conclusion}

We conclude that small scale miners at Bibiani work site are occupationally exposed to excess mercury which may affect their renal integrity. PPE compliance is low among the study participants.

\section{Abbreviations}

ASGM: Artisanal Small Scale Mining; eGFR: Estimated Glomerular Filtration Rate; PPE: Personal Protective Equipment

\section{Acknowledgements}

The authors wish to acknowledge the contribution and help of all the workers of Bibiani Government Hospital Laboratory Staff and the University of Cape Coast Hospital Laboratory Staff

\section{Ethical approval and consent to participate}

The Institutional Review Board of the University of Cape Coast gave their approval for the commencement of the study (Ethical Clearance ID: UCCIRB/ CHAS/2016/61) Participants were fully informed about the purpose, procedures, risks, and benefits of participating in this study. Written Informed consent was sought from participants (human subjects) before recruitment. A copy of the laboratory findings was sent to the small-scale gold mining committee in Bibiani District to be made accessible to the participants and a copy was given to Bibiani District Health Directorate for medical attention.

\section{Funding}

The study was self-funded by the contributing authors

\section{Availability of data and materials}

The datasets used and/or analysed during the current study will be deposited in the archives of Medical Laboratory Technology Department Library and is available from the corresponding author on reasonable request.

\section{Authors' contributions}

JA and SEB-conceived the study, contributed to the study design, questionnaire design, data collection and analysis, manuscript preparation. RKDE and DN-contributed to the preparation and finalization of the manuscript and data analysis. DOD- contributed to data collection and preparation and finalization of the manuscript. All authors confirm that this manuscript has not been previously published and is not being considered for publication in any other journal. All authors read and approved the final manuscript.

\section{Competing interests}

The authors declare that there are no financial or non-financial competing interest.

\section{Consent for publication}

Not Applicable.

\section{Publisher's Note}

Springer Nature remains neutral with regard to jurisdictional claims in published maps and institutional affiliations.

Received: 5 December 2016 Accepted: 19 June 2017

Published online: 27 June 2017

\section{References}

1. Jønsson JB, Fold N. Mining 'from below': taking Africa's artisanal miners seriously. Geography Compass. 2011;5(7):479-93.

2. Mensah EK. Exposure of Small Scale Gold Miners in Prestea to Mercury, Ghana. 2012. University of Ghana.

3. Risher JF, Amler SN. Mercury exposure: evaluation and intervention: the inappropriate use of chelating agents in the diagnosis and treatment of putative mercury poisoning. Neurotoxicology. 2005;26(4):691-9.

4. Zahir $F$, et al. Low dose mercury toxicity and human health. Environ Toxicol Pharmacol. 2005;20(2):351-60.

5. Carvalho $\mathrm{CM}$, et al. Inhibition of the human thioredoxin system a molecular mechanism of mercury toxicity. J Biol Chem. 2008;283(18):11913-23.

6. Nordman H, Berlin M. Titanium. Handbook on the Toxicology of Metals. 1986;2(1).

7. Hilson G. Challenges with eradicating child labour in the artisanal mining sector: a case study of the Talensi-Nabdam District, upper east region of Ghana. Reading: University of Reading; 2009.

8. Hilson G. Harvesting mineral riches: 1000 years of gold mining in Ghana. Resources Policy. 2002;28(1):13-26. 
9. Kelleher P, Pacheco K, Newman LS. Inorganic dust pneumonias: the metalrelated parenchymal disorders. Environ Health Perspect. 2000;108(Suppl 4):685.

10. Obiri $\mathrm{S}$, et al. Evaluation of lead and mercury neurotoxic health risk by resident children in the Obuasi municipality, Ghana. Environ Toxicol Pharmacol. 2010;29(3):209-12.

11. Hoedoafia, M.A., B.S.N. Cheabu, and V. Korang, The Effects of Small Scale Gold Mining on Living Conditions: A Case Study of the West Gonja District of Ghana. 2014, 2014: p. 14.

12. Macdonald, K.F., et al., Regulation of artisanal small scale gold mining (ASGM) in Ghana and Indonesia as currently implemented fails to adequately protect aquatic ecosystems. 2014.

13. DepartmentofHealth. Understanding Mercury Exposure Levels. 2016 [cited 2016 12-10-2016]

14. Mensah, E.K., et al., Exposure of Small-Scale Gold Miners in Prestea to Mercury, Ghana, 2012. The Pan African Medical Journal, 2016. 25(Suppl 1).

15. Adimado A, Baah D. Mercury in human blood, urine, hair, nail, and fish from the Ankobra and Tano River basins in southwestern Ghana. Bull Environ Contam Toxicol. 2002;68(3):339-46.

16. Ekawanti A, Krisnayanti BD. Effect of mercury exposure on renal function and hematological parameters among artisanal and small-scale gold miners at Sekotong, West Lombok. Indonesia Journal of Health and Pollution. 2015; 5(9):25-32.

17. Lafayette R, Perrone R, Levey A. Laboratory evaluation of renal function. Diseases of the kidney. 2001;1

18. Toora, B. and G. Rajagopal, Measurement of creatinine by Jaffe's reactiondetermination of concentration of sodium hydroxide required for maximum color development in standard, urine and protein free filtrate of serum. 2002.

19. Ephraim RK, et al. Prevalence of chronic kidney disease among the high risk population in South-western Ghana; a cross sectional study. Canadian journal of kidney health and disease. 2015;2(1):1.

20. Williams $C R$, et al. Mercury concentrations at a historically mercurycontaminated site in KwaZulu-Natal (South Africa). Environ Sci Pollut Res. 2011;18(7):1079-89.

21. Drake PL, et al. Occupational exposure to airborne mercury during gold mining operations near El Callao, Venezuela. Int Arch Occup Environ Health. 2001;74(3):206-12.

22. Chen $C$, et al. Increased oxidative DNA damage, as assessed by urinary 8hydroxy-2'-deoxyguanosine concentrations, and serum redox status in persons exposed to mercury. Clin Chem. 2005;51(4):759-67.

23. de Kom JF, van der Voet GB, de Wolff FA. Mercury exposure of maroon workers in the small scale gold mining in Suriname. Environ Res. 1998;77(2):91-7.

24. Clarkson TW. The three modern faces of mercury. Environ Health Perspect. 2002;110(Suppl 1):11.

25. Augusti PR, et al. Effect of lycopene on nephrotoxicity induced by mercuric chloride in rats. Basic \& clinical pharmacology \& toxicology. 2007;100(6):398-402.

26. Kobal $A B$, et al. Renal function in miners intermittently exposed to elemental mercury vapour. Arhiv za higijenu rada i toksikologiju. 2001; 51(4):369-80.

27. Park J-D, Zheng W. Human exposure and health effects of inorganic and elemental mercury. J Prev Med Public Health. 2012;45(6):344-52.

28. Franko A, Budihna MV, Dodic-Fikfak M. Long-term effects of elemental mercury on renal function in miners of the Idrija mercury mine. Ann Occup Hyg. 2005;49(6):521-7.

29. Devillé, W.L., et al., The urine dipstick test useful to rule out infections. A metaanalysis of the accuracy. BMC urology, 2004. 4(1): p. 1.

30. Zalups RK, Lash LH. Advances in understanding the renal transport and toxicity of mercury. Journal of Toxicology and Environmental Health, Part A Current Issues. 1994;42(1):1-44.

31. Holmes $P$, James $K$, Levy $L$. Is low-level environmental mercury exposure of concern to human health? Sci Total Environ. 2009;408(2):171-82.

32. Schwartz JG, Snider TE, Montiel MM. Toxicity of a family from vacuumed mercury. Am J Emerg Med. 1992;10(3):258-61.

33. UNEP WHO. Guidance for identifying populations at risk from mercury exposure. 2008. Geneva: United Nations Environment Programme, World Health Organization; 2008.

34. Hilson G, Hilson CJ, Pardie S. Improving awareness of mercury pollution in small-scale gold mining communities: challenges and ways forward in rural Ghana. Environ Res. 2007;103(2):275-87.

35. Rojas M, Drake PL, Roberts SM. Assessing mercury health effects in gold workers near El Callao, Venezuela. J Occup Environ Med. 2001;43(2):158-65.

\section{Submit your next manuscript to BioMed Central and we will help you at every step:}

- We accept pre-submission inquiries

- Our selector tool helps you to find the most relevant journal

- We provide round the clock customer support

- Convenient online submission

- Thorough peer review

- Inclusion in PubMed and all major indexing services

- Maximum visibility for your research

Submit your manuscript at www.biomedcentral.com/submit 